\title{
The Application of Padlet in Teaching and Learning of Writing Recount Text at Senior High School in Palu City
}

\author{
E Mulyadi ${ }^{1}$, A Naniwarsih $^{2}, \mathrm{~F} \mathrm{~A} \mathrm{Omolu}^{3}$, I Manangkari $^{4}$, and D Rara Amiati ${ }^{5}$ \\ \{ernitasarim@yahoo.com ${ }^{1}$, andi.naniwarsih18@gmail.com ${ }^{2}$, fikalu@yahoo.com ${ }^{3}$ \} \\ Faculty of Teacher Training and Education, English Department, Universitas Muhammadiyah Palu, \\ Centra Sulawesi 94118, Indonesia
}

\begin{abstract}
Writing skill is one of the essential skill in English language skills that should be mastered by Senior High school students. Meanwhile, writing is perceived as one of the most challenging and less attractive skills to be learned. The application of Padlet as a learning media is an alternative strategy for motivating and promoting students to write. Therefore, this study attempted to provide transparent information of the integration technology in teaching and learning English writing skills, particularly in writing recount text using Padlet, and how the student's response and attitude toward the use of Padlet in the writing process. This research applied a case study and conducted at Grade Eleventh, Madani Senior High School. The data were collected through observation, interviews obtained from the teacher, and questionnaires for the students. The researcher employed a Qualitative approach in analyzing the data. The findings show that students accepted the application of Padlet in conducting the teaching and learning process, it gives a positive effect on the students learning performance: 1. it was about $85 \%$ student can do the task collaboratively and 'cooperatively, 2 . students were motivating and participating actively in-class activities. These findings suggest that the use of Padlet can be implemented at other schools in Palu City.
\end{abstract}

Keywords: Padlet, teaching and learning, writing skill, recount text.

\section{Introduction}

Writing skill is a Productive skill. According to [1], writing is a productive skill, and it is a creative act in expressing ideas, writing also can help the students to explore their thoughts and feeling. That means that productive skill refers to the skills that enable the learner can produce the language in written forms using words or sentences. They can communicate with others or express their idea or thought through written text, other than orally.

Writing skill is one of the English language skills that should be mastered by High School students. [2] outlined that the English learning scope for the eleventh-grade students is to be interpersonal discourse, transactional and functional, logic and coherent rhetoric, communication, and potential academic development in five practical speech such as; recount, narrative, procedure, descriptive, and report. One of the writing text Genre and Language function should be taught Recount text. [3] stated that recount text is to list and describe past experiences by retelling events in which they happened (chronological order). This recount text aims to provide the audience with information about what and when it occurred. In 
response to the above statement, the student would construct their idea or write things based on their experience.

However, as in reality, writing is considered one of the most challenging skills for second and foreign language learners to master. The students seem reluctant to focus on writing activities, and they have less enthusiasm and confidence in writing. Several reasons for the reluctance; most students rarely write even in their language. Writing activities is not a habit for them, and most students are unfamiliar with conveying their idea and thought or telling their personal experience in writing. Moreover, the students could not write both free writing and writing systematically in the previous grade. Other reasons are they have no idea to say and do not know what to say.

Motivation is one of the critical success of a student in writing, and it is required to stimulate students' eagerness in writing. A strong effort from the students itself is needed to arouse their writing motivation. Students' inner motivation will influence the learning process they experience in. The higher intrinsic motivation they have the more encouraged they will be. Moreover, the higher innate (intrinsic) learning motivation the students possess, the more possible they achieve competence and skills from the intake process. However, other factors such as the teaching method and the availability of teaching and learning facilities will also build students' confidence in writing.

The numerous available facilities such as IT in writing and high intrinsic motivation from the students would interest them in the writing process. In line with [4] emphasized that technology makes learners' learning exciting and interactive and increased their motivation, social interactions, and engagement. It can be inferred that the proper use of technology can determine the students' cause to write. Technology has a particular role in motivating students, and it can be called intake learning process motivation because the motivation is gained from the previous learning experience.

The rapid development of technology provides positive educational changes, particularly in language teaching and learning. The use of technology can facilitate the students and teacher in the teaching and learning process. Students have ample opportunities to acquire more knowledge. They can even create an enjoyable learning environment themselves, such as the use of Multimedia Technology, featuring audio, visual, animation effects, and social media in the learning process. The internet provides easy, immediate, and virtually unlimited access to software and applications which can facilitate and speed up the English teaching and learning process.

One of the innovations of the teaching and learning of writing skills is applying the technology (Padlet) or known before as wall-wisher. This study investigates the application of Padlet in the teaching and learning process of writing recount text, students' learning performance, and giving an overview of how the student's response and attitude toward the use of Padlet in the writing process. Padlet is one of the online media can be used as an alternative way of teaching writing skill. According to [5], Padlet gives a free application, a multimediafriendly wall used to encourage real-time, and promotes full class participation and assessment. Applying Padlet in the teaching and learning process has some advantages. The use of Padlet fosters students' creativity, students can modify the information using the text, but they can also easily use the multimedia element to enrich their knowledge. Students can upload videos, images, documents, and PDFs, share links, or provide comments on each other's posts, or they can create public or private walls.

Padlet also promotes collaborative and cooperative learning. This idea is supported by [6] several platforms that can encourage students to collaborate in the writing process either in the classroom or in virtual learning, such as blogs, Facebook, wikis, and Padlet. Using Padlet in 
the writing learning process makes it easier for students to work collaboratively. They can post their paragraph writing or essay on the wall, and other students would give the comments either as suggestions or corrections. They can enrich their knowledge and learn from each other. Furthermore, conducting the writing assignments collaboratively has been shown to enhance the students' interaction, lower anxiety in completing the tasks, and raise students' self-confidence. [7] Hence, using Padlet in writing assignments will allow students to enjoy writing jobs and complete them on time. It is reasonable because if a teacher can apply Padlet in teaching writing skills and presenting writing assignments correctly, it will allow students to learn from each other and independently. Besides, it has a prospective motivation space for students and to increase their learning curiosity to write.

\section{Method}

This research employed a qualitative method, and the data were obtained from the participants through interviews and questionnaires, and other supporting data collected from the observation checklist and field notes. The research was conducted at SMA Negeri Model Madani Palu and involved 31 participants from eleventh-grade students and 1 English teacher. The data obtained from the teacher's consultation is the information on how she/he integrates the technology in teaching and learning, particularly in teaching writing recount text using Padlet media. The data collected from the students are several questions related to how their response and attitude toward the use of Padlet in the teaching and learning process, particularly in learning writing recount text.

All those data from the interview, questionnaires, observation, and field notes were analyzed descriptively. In order to find a valid data, this research employed Triangulation to cross check the validity of the data. Triangulation is also commonly known as multiple methods or data sources to developed comprehensive understanding about phenomena. Cross validity means to cross check the validity of the data gained from different participants or different data sources; in other words cross validity in Triangulation is to test validity through the convergence of information from different sources.

\section{Results and Discussion}

Padlet is an online application or virtual wall to be used for the interaction between students and teachers. During this current situation, where most schools still conduct the teaching and learning process through online platforms due to the outbreak of coronavirus pandemic, Padlet is one of the most suited media because it can facilitate the teacher and students' teaching-learning process, particularly in writing skill.

Before constructing or assigning the students to do the task, they are first introduced to the application of Padlet, such as how it's used and what its benefits toward the learning process, particularly in writing skill. Then students were trained to operate Padlet using their devices such as laptops, smartphones, or tablets.

The findings of the research present three kinds of data: the application of Padlet in the teaching and learning process, particularly in writing recount text; the effects of using Padlet on students' learning performance; and the student's response and attitude toward the use of Padlet in the writing process. 


\subsection{The application of padlet}

Several superiorities of using Padlet media in the teaching and learning process, particularly in improving both aspects; students' learning skills, particularly in writing skills and students' learning elements such as collaboration, engagement, imagination, creativity, good relationship and self-evaluation.

Following is the teaching steps using Padlet application as media in the process of teaching and learning writing skills, particularly in writing recount text.

Table 3.1 The teaching and learning writing stages through padlet.

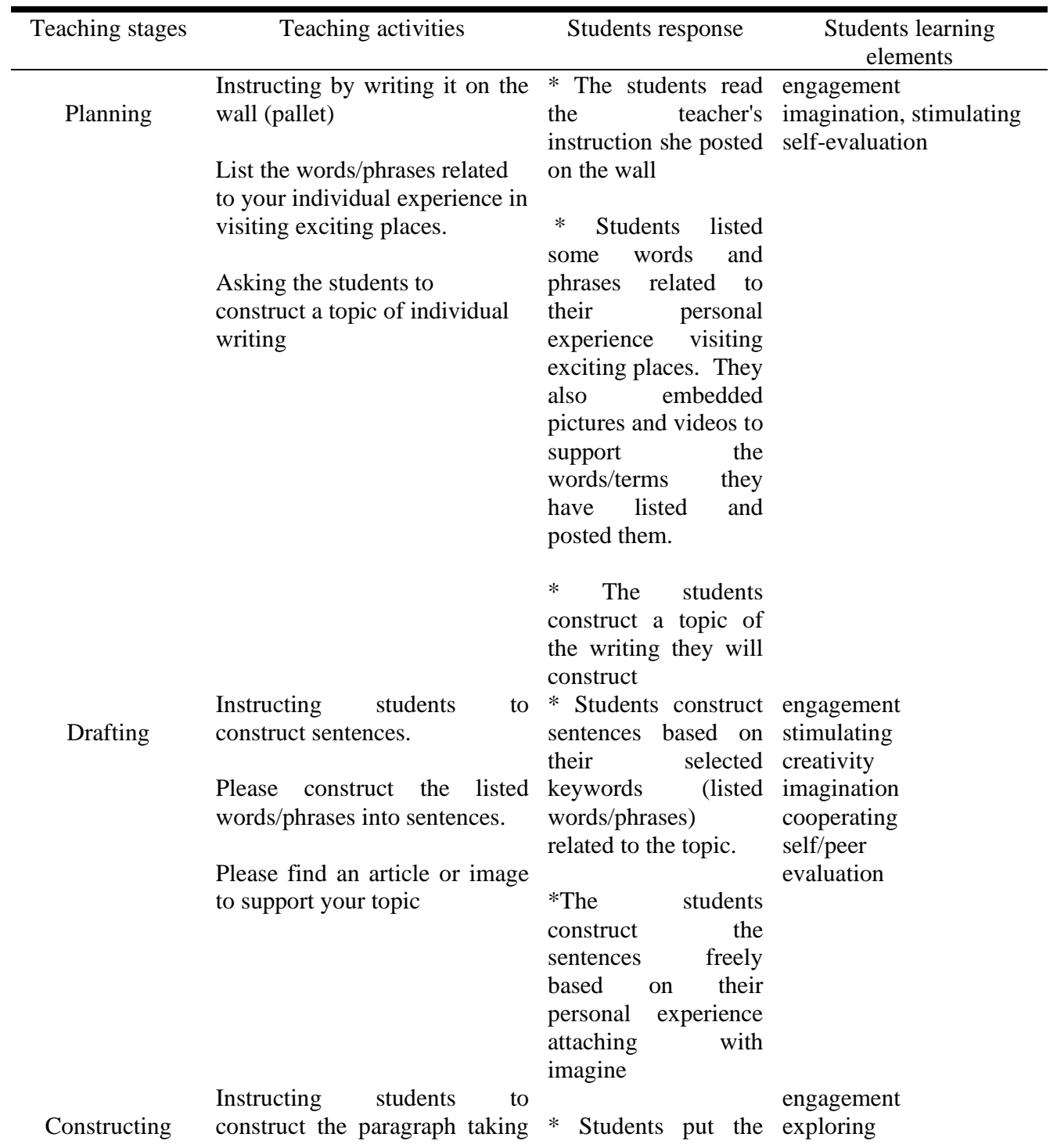


from the sentences the students sentences into have built them in the drafting paragraph. stage

Please construct a simple writi paragraph by the wall, and the employing the simple sentences classmates can see it you have been built in the drafting stage into a good paragraph

Revising Instructing students to change their paragraph writing.

Identify the content of your writing and your idea's structure and rearrange them identification, peer into a suitable sequence of and teacher events for coherence.

evaluation during drafting until completing the process.

The student might be adding, rearranging, removing, or replacing the idea they have written for coherence.

Editing

Instructing students to identify the mistake in grammatical components of their writing * The identify the words, spelling,

Identify inappropriate words, punctuation students engagement phrases, and sentences in your edition paragraph and replace them with a suitable one.

* The students post

Asking students to contribute the result of their their suggestion for classmates' correction in edition

Publishing

self-evaluation peer evaluation creativity

engagement the paragraph they self-evaluation creativity edition misused self-evaluation phrases, peer evaluation and creativity and ost (cin

(1)

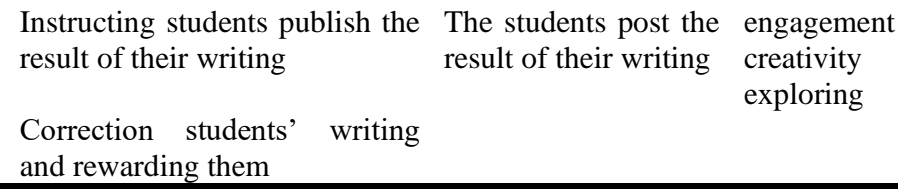
teacher correction 
planning showed a significant result since all students could list words and phrases on the wall and constructed them into the writing topic they were going to make. [8] highlighted that Padlet is an influential media that facilitates project work, class discussion, and brainstorming. Similarly, [9] concluded that Padlet is a versatile online interactive tool that boosts learners' creativity and enthusiasm to collect and share ideas. The use of Padlet in the writing process allows every student to participate and freely send their thoughts on the wall (Padlet site). They can post their writing or asking questions without feeling embarrassed because they may post them anonymously.

2) Drafting is the second stage in the writing activity. In this stage, again, the teacher instructed the students to recall the English words and phrases they have listed and asked them to construct them into simple sentences. The students were free to build more simple sentences before the teacher asked them to put them into a simple paragraph. The result of observation indicated high student participation in drafting activity. They enjoy drafting training by constructed two or more simple sentences and present those sentences on the wall so that all students can read them.

3) Constructing. Constructing in a writing activity means to arrange some simple paragraph. Before having been in the construction activity, the teacher asked the students to recall the sentences they constructed in the drafting stage. It was meant to make it easier to build a paragraph. In this stage, some students found it was difficult to arrange some sentences into a simple paragraph. They got stuck when they put sentences chronologically to write a recount text. This problem required more time for them to do a repetition to construct a well-arranged sentence in a meaningful paragraph. Some students even asked their classmates for suggestions to have good paragraph construction after they posted the section. Most students could present two paragraphs on the wall; even though there was still a small number of them, they were confused about arranging sentences into an acceptable section.

4) The fourth stage is revising. In the revising stage, the students modify the structure of the writing, content, sequence event, and the coherence among the sentences.

5) The fifth stage is editing. The edition changes the text by adding, deleting, and rearranging letters, words, sentences, and paragraphs. In this writing process, the students edit their writing by identifying mistakes in grammar, spelling, punctuation, and capitalization.

6) The last stage of writing is publishing. In this publishing process, the students posted their final texts or paragraphs they have constructed, the teacher corrected and scored them.

\subsection{The effects of using Padlet on students' learning performance}

The use of educational technology media facilitates the teaching and learning process. The application of Padlet as one of the technologies media offers some effects to both teacher and students. The following presented data in (table 3.2) describes the impact of using Padlet on students learning performance. 
Table 3.2 The effects of using Padlet on students' learning performance.

\begin{tabular}{|c|c|c|c|c|}
\hline \multirow[t]{2}{*}{ No } & \multirow[t]{2}{*}{ Criteria } & \multicolumn{3}{|c|}{ Result } \\
\hline & & High & Medium & Low \\
\hline 1 & $\begin{array}{l}\text { The students participate actively in English } \\
\text { writing class taught by using Padlet }\end{array}$ & $\sqrt{ }$ & & \\
\hline 2 & $\begin{array}{l}\text { The students have more chances to learn and } \\
\text { practice writing skills. }\end{array}$ & $\sqrt{ }$ & & \\
\hline & $\begin{array}{l}\text { The students are encouraged to complete the } \\
\text { classroom task by posting their work on the }\end{array}$ & & & \\
\hline 3 & wall. & $\sqrt{ }$ & & \\
\hline & $\begin{array}{l}\text { The students are encouraged and motivated to } \\
\text { evaluate their writing based on peers' }\end{array}$ & & & \\
\hline 4 & evaluation and teacher's correction. & $\sqrt{ }$ & & \\
\hline 5 & $\begin{array}{l}\text { The students improve their writing and do self- } \\
\text { assessment by reading their classmates' works. }\end{array}$ & & $\sqrt{ }$ & \\
\hline 6 & $\begin{array}{l}\text { The teaching and learning process is more } \\
\text { interactive through Padlet media. }\end{array}$ & $\sqrt{ }$ & & \\
\hline 7 & $\begin{array}{l}\text { The students tend to do the task cooperatively } \\
\text { and collaboratively. }\end{array}$ & $\sqrt{ }$ & & \\
\hline
\end{tabular}

Applying Padlet in the writing process from drafting to the final stage of publication generates the students' motivation and self-confidence in learning; they are actively participating in the learning process. The presented data shows that a high result of students' participation in English writing class using Padlet. It was also found that students have more chances to learn and to practice writing skills attentively. The findings [10] stated that the use of Padlet could enhance the student's learning experience that allows them to engage with subject material.

The student's motivation and participation in posting their writing shows a high result; they are encouraged to complete the task by publishing their work on the wall. They are enthusiastic about posting their job due to their curiosity to have the new experience of using Padlet as a learning tool in their writing exercise. Moreover, they have more chances to post their writing product to represent their developing writing creativity. They are experienced in posting their photographs, personal videos, links, or images on the wall.

Besides posting photographs, personal videos, images, and links on the wall, the students were also motivated to have corrections on their writing product based on peers' evaluation and teacher's correction. Peer feedback or peer evaluation is a crucial factor in raising students' motivation.

The finding is in line with [11] pointed out that Padlet increased the learner's motivation towards writing through peer evaluation, and it also improved their writing performance. [12] stated that the use of Padlet raised learners' participation in the discussion process as it allowed them to have experienced authentic communication with a real audience, classmates, and teacher. Both of the studies above support the findings of the present study; improved on students' learning elements, raised in student motivation, and the activeness of students' participation in-class activities. All those aspects can positively affect students' learning performance and English skill achievement, particularly in writing skill.

The finding on point 5 shows a medium result. The students do a self-assessment on their writing product and improve their writing skills by reading their classmates' work. It can be 
interpreted that the students do not like imitating others' work to correct on his/her own. The last finding shows a high result on the criteria in point 7 - they do the task cooperatively and collaboratively. The integration of technological learning tools in the teaching and learning process has made the most significant change in teaching method from the teacher-centered to student-centered. [13] The results of integrating technology learning tools have given many benefits to students. The study by [14] showed that the use of Padlet helps students enhance their skills, especially in writing, communication, and collaboration. The use of Padlet facilitates communication and cooperation among students.

\subsection{The effects of using Padlet on students' attitude and learning motivation}

As mentioned previously, the use of Padlet media is beneficial to students' writing skills and positively affects students' attitude and learning motivation. The following table is the data presentation on how the use of Padlet affects the students' attitude and students' learning motivation.

Table 3.3 The effects of using Padlet on students' attitude and learning motivation.

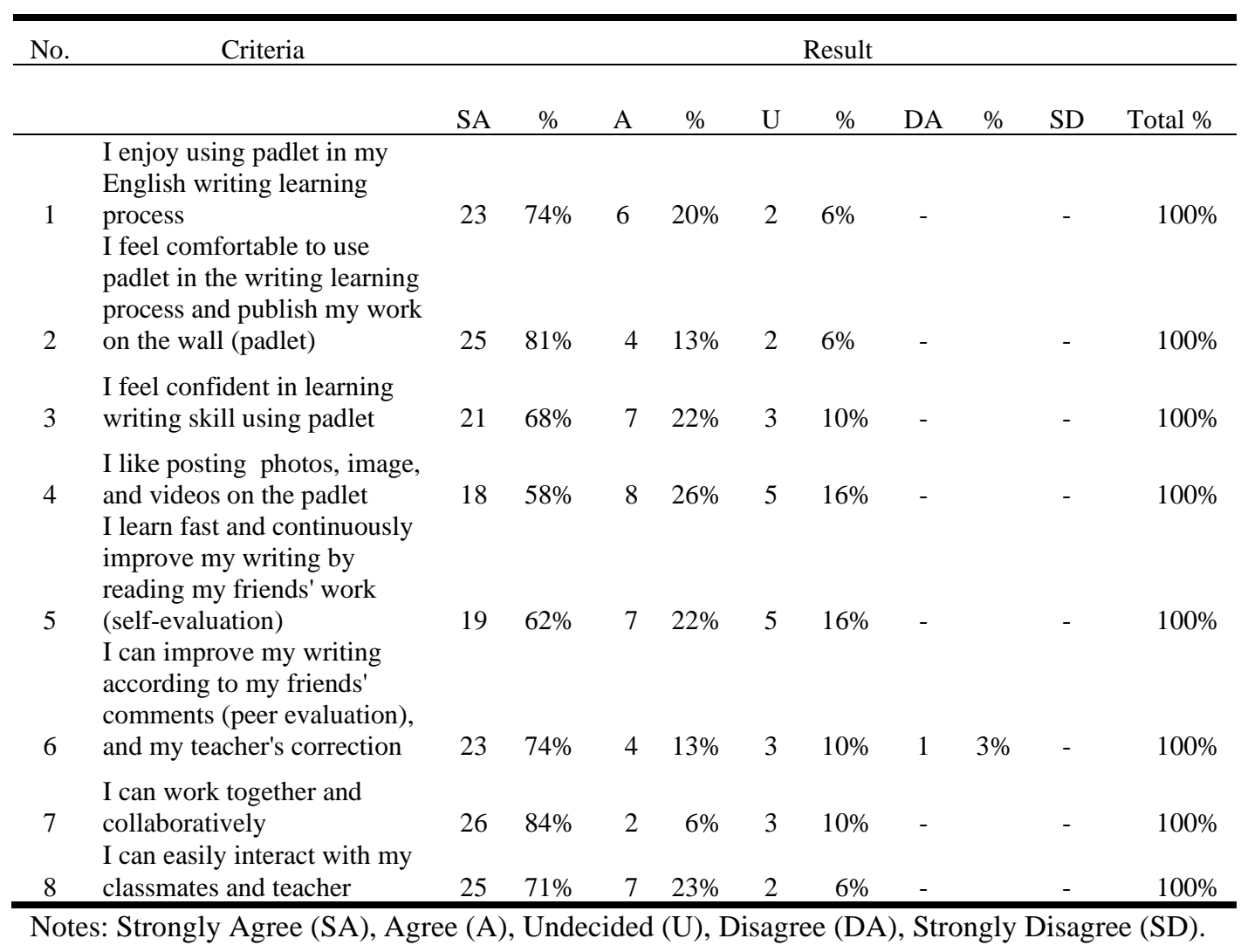


The findings in table 3.3 above relate to the student's response, attitude, and learning motivation toward the use of Padlet in the learning writing process. The study found that from 31 participants, 23 or $74 \%$ strongly agreed that "they enjoy using Padlet in learning English writing skill." Meanwhile, six students or $20 \%$ of the total participants stated that they agree, and the rest 2 or $6 \%$ of participants could not decide whether they agree or disagree.

Based on the presented data in the table above, almost all students have no difficulties in applying Padlet in the learning process, even though they have no experience of using it before. The data showed that about $81 \%$ of the total number of participants strongly agreed that they feel comfortable using Padlet in the writing learning process. They can easily publish their work on the wall; meanwhile, only less than $10 \%$ are undecided with the answer.

Moreover, $68 \%$ of participants strongly agreed that they feel confident in learning writing using Padlet, and about $10 \%$ undecided with the answer. They were encouraged to post their report not only; as shown on the table above, 58\% of participants also enjoy sharing their photos, images, or videos on the wall. So, it is reasonable to indicate that technology promotes student learning independently and helps them build their confidence in learning English writing skills.

As shown in the table above, $74 \%$ of participants strongly agreed that they could improve their writing based on their classmates' comments and teacher's correction. Participants can evaluate their work through peer evaluation and correction from their teacher. It is one of the advantages of using Padlet in teaching writing skills. The use of technology has improved students' critical thinking skills. They are motivated to learn and develop their writing skills enthusiastically. [15]

The next research findings were that approximately $71 \%$ of participants strongly agreed that the use of Padlet makes it easier to interact with their classmates and their teacher. It is in line with [16] stated that using Information and Technology in teaching and learning will be more effective in education environments where teacher and learners can interact easily and exchange information and experiences. The interaction between students and their teacher will make the learning experience more effective and meaningful. Therefore, the students become more motivated to learn more, and in turn, they can improve their writing performance.

The last finding of the research was that the use of Padlet in studying writing skills could encourage students to work collaboratively. It was found that almost $85 \%$ of the participants stated that I could work together and collaboratively. It means that the students enjoy the learning process using Padlet because they can revise and edit their writing product.

\section{Conclusion}

Based on the research findings and discussion above, several superiorities of using Padlet media in the teaching and learning process particularly in improving on students' learning skills (students'writing skills) and students' learning elements such as engagement, creativity, cooperation, and collaboration. The application of Padlet also offer some positive effects on students' learning performance; the students become more actively in participating English writing skill class, and have experienced improving on their writing skill through self, peer evaluation and correction from their teacher. The use of technology makes the teaching and learning process become more interactive and increased the students' motivation. 
The use of Padlet in writing class help students not only in improving the students' academic writing skill but also more helping them to build up their soft skills such communication, collaboration, creativity and critical thinking, all those skills are categorized as one of the 21 st-century learning skills; commonly called in four $\mathrm{C}$; communication, collaboration, critical thinking, and creativity.

Acknowledgements. This work was particularly supported by Muhammadiyah University of Palu, Central Sulawesi, Indonesia.

\section{References}

[1] Wyrick J. Steps to Writing Well with Additional Readings [Internet]. Eighth Edi. United States: WADSWORTH CENGAGE learning; 2013. 768 p. Available from: https://books.google.com/books?hl=en\&lr=\&id=UXEWAAAAQBAJ\&pgis=1

[2] Wahyudin AY, Sukyadi D. A Closer Look at the Implementation of the Curriculum 2013 in Indonesia: Should the Scientific Approach Be Used in EFL Classroom? Natahdibrata [Internet]. 2019;2(2). Available from: https://www.researchgate.net/publication/308716197

[3] Hidayat RW, Setyowati L, Mabaroh B. Genre - Based Approach for Writing Recount Text at MTs "Darul Ulum” Karang Pandan, Pasuruan. J Bhs Ling Sci. 2018 Jun 5;10(1).

[4] Baytak A, Tarman B, Ayas C. Experiencing technology integration in education: Children's perceptions. Int Electron J Elem Educ. 2011;3(2):139-51.

[5] Fuchs B. The Writing is on the Wall: Using Padlet for Whole-Class Engagement The Writing is on the Wall: Using Padlet for Whole-Class Engagement. LOEX Q. 2014;240(4):7.

[6] Savelyeva T. M. Spector, D. Merrill, J. Elen, M. J. Bishop (eds): Handbook of Research on Educational Communications and Technology. Technol Knowl Learn. 2014 Apr;20(1):123-8.

[7] Mulligan C, Garofalo R. A collaborative writing approach: Methodology and student assessment. Lang Teach. 2011;35(3):5.

[8] Mahmud MZ. Students' perceptions of using Padlet as a learning tool for English writing. J Creat Pract Lang Learn Teach. 2019;7(2):29-29.

[9] Lysunets T B \& Bogoryard N V. Padlet And Other Information Communication Technology Tools In English Language Teaching. Mod Res Soc Probl. 2015;10(54):413-23.

[10] Ellis D. Using Padlet to increase student engagement in lectures CURVE is the Institutional Repository for Coventry University. 2015;29(February).

[11] Nina S. Nina Septina-EF English First Semarang Winda Hapsari-LBPP LIA Jakarta for Virtual Workshop Overview Background and Purpose of Study. 2015.

[12] Dewitt D, Alias N, Siraj S. Collaborative learning: Interactive debates using Padlet in a higher education institution. Turkish Online J Educ Technol. 2015;2015:88-95.

[13] Awaludin FA, Abd Karim R, Mohd Saad NH. Padlet: A Digital Collaborative Tool for Academic Writing. J Educ Soc Sci. 2017;8(1):179-84.

[14] Dewitt D, Alias N, Siraj S. Collaborative Learning: Interactive Debates Using Padlet In A Higher Education Institution. 2017.

[15] Fageeh A I. Effects of Blogging on Enhancing Writing Skills and Attitudes towards English Learning in an EFL Context Abstract. 2011;

[16] Zhang C. A study of internet use in EFL teaching and learning in Northwest China. Asian Soc Sci. 2013;9(2):48-52. 